\title{
Phytopharmacological and ethnomedicinal uses of the Genus Berberis (Berberidaceae): A review
}

\author{
Ibrahim Khan*, Syed Najeebullah, Muhammad Ali and Zabta Khan Shinwari \\ Department of Biotechnology, Quaid-i-Azam University, Islamabad, Pakistan
}

${ }^{\star}$ For correspondence: Email: ibrahimkhan.qau@gmail.com; Tel: +92-03215581082

Received: 8 April 2016

Revised accepted: 17 August 2016

\begin{abstract}
Plants belonging to Berberis are reported in several folklore medicinal pharmacopeias and are used in traditional medicines in Asia and European countries. The plants have been used in the preparation of various traditional and synthetic medicines since pre-historic times for wound healing, fever, eye disease, jaundice, vomiting during pregnancy, rheumatism, kidney and gall balder stones, and several other illnesses. Their healing properties are appear to be due to the presence of secondary metabolites and important alkaloids with different pharmacological activities. Their antibacterial, antifungal, antiviral, anti-diabetic, and anti-tumor activities as well as positive effects on the cardiovascular and body immune systems have been reported. Root extracts of some species of the plant genus contain quinine which acts as a powerful anti-malarial agent. The main chemical constituents of Berberis plants are alkaloids, steroids, glycosides, flavonoids, saponins, terpenoids and reducing sugars. Of these alkaloids, berberine is the most important. The present review focuses on recent advances in phytopharmacological and ethnomedicinal uses of plants belonging to Berberis genus.
\end{abstract}

Keywords: Berberis, Alkaloids, Berberine, Pharmacology, Phytochemistry, Ethnomedicinal uses

Tropical Journal of Pharmaceutical Research is indexed by Science Citation Index (SciSearch), Scopus, International Pharmaceutical Abstract, Chemical Abstracts, Embase, Index Copernicus, EBSCO, African Index Medicus, JournalSeek, Journal Citation Reports/Science Edition, Directory of Open Access Journals (DOAJ), African Journal Online, Bioline International, Open-J-Gate and Pharmacy Abstracts

\section{INTRODUCTION}

Traditionally medicinal plants have been used in the preparation of medicines [1,2]; In developing countries, about $25 \%$ of ingredients in prescribed medicines are derived from medicinal plants [2,3]. Most of these preparations include plant extracts and their active components. In addition, a number of modern drugs are isolated from natural medicinal plants [4].

The genus, Berberis, is a major dicotyledonous genus belonging to the Berberidaceae family; mainly spiny, woody, deciduous or evergreen shrubs or small trees with characteristic yellow wood and flowers. Different taxonomists have reported different number of species in this genus. Recent reports indicate 17 genera and 650 species of Berberidaceae [5]. The genus has wide distribution all over the world mainly in India, Pakistan, Japan, China, Central and West Asia, South-East Asia, Europe, East Africa, South America and North America [6]. In Pakistan, species belonging to this genus are found across most of the mountainous regions $(1400 m-3500 m$ above sea level) and are key components of both traditional and modern medicines [5,7-9]. Based on habitat, these plants are clustered into three groups namely Rocky Mountain group which includes $B$. aquifolium Pursh, the Asiatic group which includes $B$. aristata and the European group which includes $B$. vulgaris [11]. Apart from their medicinal uses, 
some of the species are also used as sources of natural dyes $[10,12]$.

Research findings have been published by various groups on the phytochemical and pharmacological properties of Berberis species. Ikram [13] reviewed studies on the chemical and pharmacological aspects of 24 Berberis species. The number of chemical studies on Berberis species increased immensely between 1975 and 1990. Karimov [14] also tabulated 76 Berberis species and listed 129 distinct new alkaloids belonging to 16 different classes. The present review focuses mainly on recent advances in different ethno-medicinal uses and pharmacological studies of chemical substances from plants belonging to genus Berberis. In addition we discussed the biological activities of chemical compounds found in Berberis species, and their relevance to phyto-medicinal properties.

\section{PHYTOCHEMISTRY OF GENUS BERBERIS}

Almost similar types of chemical constituents are present in the roots and stems of Berberis plants. However, variations exist in the chemical constituents of leaves of different species of the genus [11]. These include alkaloids, flavanoids, terpenoids, anthocyanins, sterols, vitamins, lignins, carotenoids, proteins and lipids which have been isolated and characterized from different Berberis species (Table 1 and 2). Some of the main alkaloids reported are berberine, berbamine, columbamine, palmatine, jatrorrhizine and oxyacanthine [10,14-16]. From methanolic extract of all parts of $B$. pachyacantha an isoquinoline alkaloid, pachycanthine, was isolated [17]. Furthermore, Torres et al [18] isolated lignins from the stem and leaves of these plants.
Although most of the phytochemical studies focused on wild species, some of the research groups have carried out comparative studies on the phytochemical compositions of wild and cultivated plants of this genus. For example, differences have been reported in the amount of alkaloids isolated from wild and cultivated plants $[19,20]$. For example, Gorval and Grishkovets [21] reported that evergreen Berberis species contain more alkaloids than deciduous species.

While most of the phytochemical studies were carried out on the stem, stem bark, root and root bark of Berberis plants, there are reports of characterization of phytochemicals from other parts like leaves, fruits and flowers. Various polyphenolic flavonoids like caffeic acid, quercetin; meratin, chlorogenic acid and rutin have been extracted from the flowers of $B$. aristata. Chemical constituents present in the fruits have nutraceutical potential and provide health benefits [22]. B. lycium is a good source of various nutrients like $\beta$-carotene, anthocyanin, ascorbic acid and minerals.

Studies carried out on five different species of Berberis from West Himalaya showed that the fruits contained appreciable amounts of protein (seeds 5.9-8.5\%; pulp 4.7-7.2 \%); fat (seeds 4.6-5.3 \%; pulp 2.6-4.0 \%); fiber (seeds 4.4-5.3 $\%$; pulp 7.0-8.1\%), and minerals, especially potassium and calcium [23]. However, they have anti-nutritional factors like tannins and phytic-acid which lower food energy. Hence, care should be taken while selecting these fruits for value addition as health foods.

The major chemical constituents of different species of the genus Berberis are illustrated in Figure 1.

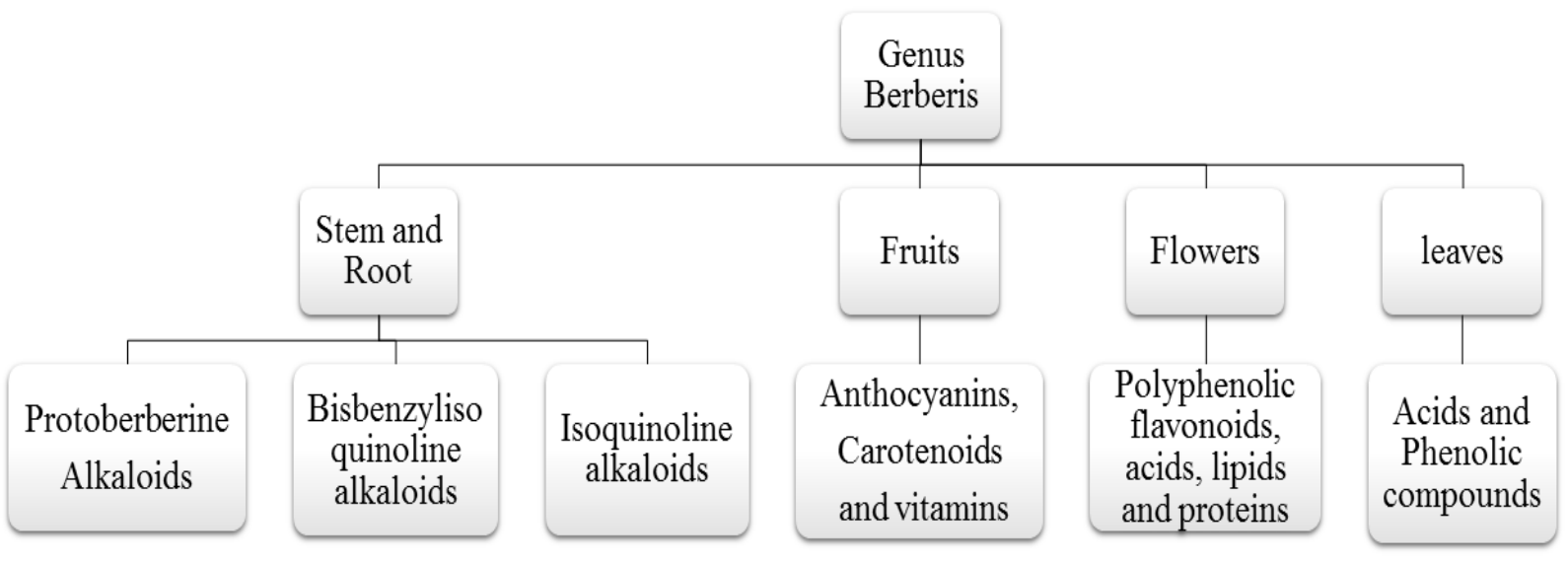

Figure 1: Major chemical constituents of different species of the genus Berberis 
Table 1: Photochemistry of Berberis plants

\begin{tabular}{|c|c|c|c|c|}
\hline No & Botanical Name & The compounds isolated & Parts used & References \\
\hline 1 & B. aristata & $\begin{array}{l}\text { Berbamine, Berberine, Colunbamamine, } \\
\text { Jatrrohirine,, Karachine, Oxyacanthine, } \\
\text { Oxyberberine, Palmatine, Palmitine, } \\
\text { Taxilamine, Tetrahydropalmitine }\end{array}$ & Roots and leaves & $\begin{array}{l}\text { Srivastava et al., } \\
\text { [14]; } \\
\text { Bhardwaj and } \\
\text { Kaushik, [9] }\end{array}$ \\
\hline 2 & B. lycium & $\begin{array}{l}\text { Baberine, Berbericine hydrochloride, } \\
\text { Berbericine hydroiodide, Berberine } \\
\text { chloride, Berberine-chlorofrom, } \\
\text { Chenabine, Diphenolic, Palmatine, } \\
\text { Gilgitine, Jhelumine, Kara-koramine, } \\
\text { Palmitine chloroform along with } \\
\text { oxyberberine, Punjabine, Seco- } \\
\text { bisbenzylisoquinolines, Sindamine, } \\
\text { Umbellatine }\end{array}$ & $\begin{array}{l}\text { Roots, Leaves, } \\
\text { Stems and } \\
\text { Decoctions }\end{array}$ & $\begin{array}{l}\text { Ikram et al., [11]; } \\
\text { Miana, [26] }\end{array}$ \\
\hline 3 & B. pachycantha & $\begin{array}{l}\text { Berbamine, Cyanidin- } 3 \text { glucoside, } \\
\text { Isotetrandrine, Jatrorrhizine, } \\
\text { Magnoflorine, Oxyacanthine, } \\
\text { Oxyberberine, Polar gonidin - } 3 \text { glucoside }\end{array}$ & Roots and Fruits & $\begin{array}{l}\text { Reviewed by } \\
\text { Srivastava et al., } \\
{[14]}\end{array}$ \\
\hline 4 & B. vulgaris & $\begin{array}{l}\text { 8-Oxyberberine, Aromoline, Auroxanthin, } \\
\text { Baluchistanamine, Berbamine, Berberine } \\
\text { Chloride, Capsanthin, Carbohydrates, } \\
\text { Chilenine Chrysanthemaxanthin, } \\
\text { Flavoxanthin, Palmatine, Isotetrandrine, } \\
\text { Jatrorrhizine Chloride, Lutein, Obaberine, } \\
\text { Obamegine, Organic acids, Oxycanthine, } \\
\text { Palmitine Chloride, Pectic substances, } \\
\text { Tannin, Tejedine, Thalifoline, } \\
\text { Thaligrisine, Vitamin C, Zea xanthin, } \beta \text { - } \\
\text { carotene }\end{array}$ & $\begin{array}{l}\text { Fruits, Root bark, } \\
\text { Decoctions and } \\
\text { Fruits }\end{array}$ & $\begin{array}{l}\text { Reviewed by } \\
\text { Srivastava et al., } \\
{[14]}\end{array}$ \\
\hline 5 & B. coriaria & $\begin{array}{l}1,4-B i s \text { ( } 2 \text { - hydroxy-5'-methylphenyl)- } \\
\text { butan-1, 4-dione (I) (a ketone), ketone -7 } \\
\text { methyltetracosan along with berberine, }\end{array}$ & $\begin{array}{l}\text { Stem, Bark and } \\
\text { Fruits }\end{array}$ & $\begin{array}{l}\text { Tiwari and Singh, } \\
\text { [29] }\end{array}$ \\
\hline & & $\begin{array}{l}\text { Anthocyanins -cyanidin, Pelargonidin, } \\
\text { Petunidin, } \\
\text { Peonidin and delphinidin aglycons } \\
\text { bounded with glucose and rutinose. }\end{array}$ & & $\begin{array}{l}\text { Srivastava et al., } \\
{[14]}\end{array}$ \\
\hline 6 & B. calliobotrys & $\begin{array}{l}\text { 1-0-methylpakistanine, Chitraline, } \\
\text { Kalashine, New dimeric aporphine } \\
\text { Benzylisoquinoline- Khyberine, } \\
\text { Pakistanamine, Pakistanine }\end{array}$ & Roots & $\begin{array}{l}\text { Hussain and } \\
\text { Shamma, [30] }\end{array}$ \\
\hline 7 & B. orthobotrys & $\begin{array}{l}\text { Dimer of kalashine with the } \\
\text { pakistanamine and pakistanine, 1-0 } \\
\text { methyl kalashine, armeparvine }\end{array}$ & Roots & $\begin{array}{l}\text { Hussain and } \\
\text { Shamma, [30] }\end{array}$ \\
\hline 8 & B. brandisiana & $\begin{array}{l}\text { Berbamine-2'- } \beta \text {-N-oxide, Berbamine, } \\
\text { Palmitine, Berbernine, Thalifoline, } \\
\text { Reticuline, Apoglaziovine, Isoboldine, } \\
\text { Isotetrandrine }\end{array}$ & Aerial parts & $\begin{array}{l}\text { Hussain et al., [31]; } \\
\text { Karimov et al., [12] }\end{array}$ \\
\hline 9 & $\begin{array}{l}\text { B. } \\
\text { pseudoumbellata }\end{array}$ & $\begin{array}{l}\text { Berberine, Palmitine, Pisbenzy } \\
\text { isoquinoline alkaloid oxyaoanthine, O- } \\
\text { methyl oxyacanthine }\end{array}$ & Aerial part & $\begin{array}{l}\text { Reviewed by } \\
\text { Rajasekaran and } \\
\text { Pant, [32] }\end{array}$ \\
\hline 10 & B. baluchistanica & $\begin{array}{l}\text { Free base baluchistanamine, Phenolic } \\
\text { aprophine benzylisoquinoline alkaloid, } \\
\text { pakistanine, Proaphorphin, } \\
\text { benzylisoquinoline alkaloid, } \\
\text { pakistanamine }\end{array}$ & Roots & Kakar et al., [33] \\
\hline 11 & B. calliobotrys & $\begin{array}{l}\text { Berberine, Oxyberberine, Karachine, } \\
\text { Corydaldine, Methylcorydaldine, } \\
\text { Nmethyl- 6, 7-Dimethoxy-isoquinoline, } \\
\text { Aromoline, Pakistanine, Waziristanine }\end{array}$ & Root bark & Ahmed, [34] \\
\hline 12 & B. jaeschkeana & $\begin{array}{l}\text { Alkaloids, Glycosides, Flavonoids, } \\
\text { Steroids, Saponins, Reducing Sugars, } \\
\text { Terpenoids }\end{array}$ & Roots and Stems & Alamzeb et al., [35] \\
\hline
\end{tabular}


Table 1: Photochemistry of Berberis plants (continued)

\begin{tabular}{|c|c|c|c|c|}
\hline No & Botanical Name & The compounds isolated & Parts used & References \\
\hline 13 & B. chitria & $\begin{array}{l}\text { Alkaloids named chitrian A, B, C, } \\
\text { Aporphine base-o-methyl corydine N- } \\
\text { oxide, Berbamine, Berbamunine, } \\
\text { Berberine, Berlambine, Cetyl alcohol, } \\
\text { Columbamine, Dihydro kaempferol, } \\
\text { Dihydropalmitine N-oxid, Glucose, } \\
\text { fructose and rhamnose, } \\
\text { Hentriacontane, Hydroxyacanthine, } \\
\text { Jatrorrhizine, Lambertine, Linoleic } \\
\text { acids, Oleic acids, Oxyacanthine, } \\
\text { Palmitic, Palmitine, Palmitine, } \\
\text { Quercetin, Steric acids, Triacontan, } \\
\text { Trimethoxyl dibenzo- quinoliziaium } \\
\text { chloride, Umbellatine, Yuziphine, } \beta- \\
\text { sitosterol }\end{array}$ & Roots & $\begin{array}{l}\text { Hussaini and } \\
\text { Shoeb, [36] }\end{array}$ \\
\hline
\end{tabular}

Table 2: Major alkaloids present in species belonging to the genus Berberis

\begin{tabular}{|c|c|c|c|}
\hline S/no. & Alkaloid & Species & Reference \\
\hline 1 & Berberine & $\begin{array}{l}\text { B. aristata, B. lycium, B. vulgaris, B. chitria, B. } \\
\text { corearia, } \\
\text { B. umbellata, B. pseudumbellata, B. jaeschkeana, } \\
\text { B. waziristanica, Berberis brevissima }\end{array}$ & Rashmi et al [34] \\
\hline 2 & Berbamine & $\begin{array}{l}\text { B. aristata, B. vulgaris, B. coriaria, B. jaeschkeana, } \\
\text { B. pachycantha, B. brandisiana, B. chitria }\end{array}$ & Rashmi et al [34] \\
\hline 3 & Palmatine & $\begin{array}{l}\text { B. aristata, B. lycium, B. vulgaris, B. chitria, B. } \\
\text { jaeschkeana }\end{array}$ & $\begin{array}{l}\text { Rashmi et al [46]; Bhardwaj } \\
\text { and Kaushik [11] }\end{array}$ \\
\hline 4 & Columbamine & B. vulgaris, B. chitria & Hussaini and Shoeb [38] \\
\hline 5 & Jatrorrhizine & $\begin{array}{l}\text { B. aristata, B. lycium, B. vulgaris, B. chitria, } B . \\
\text { pachycantha, B. vulgaris }\end{array}$ & Rashmi et al [46] \\
\hline 6 & Oxyacanthine & $\begin{array}{l}\text { B. aristata, B. chitria, B. coriaria, B. pachycantha, B. } \\
\text { pseudoumbellata, }\end{array}$ & Rashmi et al [46]; \\
\hline
\end{tabular}

Different parts of the plants have been explored for different purpose viz. the fruits of $B$. vulgaris have been explored more broadly for their neutraceutical properties in comparison to other parts. Also, the stem and roots of $B$. aristata and $B$. Iyceum (these species mainly found in Asia) have been extensively studied for their medicinal rather than for neutraceutical properties [23,24].

\section{PHARMACOLOGY OF GENUS BERBERIS}

A number of pharmacological and clinical studies have been reported for different Berberis species, thus indicating their importance as medicinal plants (Table 3). Traditionally, in 668 BC Assyrian (present day Iraqi) people used Berberis species, especially barberry fruit extracts, for blood purification [14]. In a number of homeopathic and ethno-medicines, the stem and roots of Berberis species have been extensively used as ingredients or raw materials; they are used in Ayurveda (traditional Indian medicine system) for quick healing of wounds, various infections of ear, eye and mouth, piles and hemorrhoids; for reducing obesity, for the treatment of dysentery, indigestion and vaginal diseases, and as antidotes for snake bites [39]. Extracts prepared by boiling the roots and stem barks of $B$. aristata, $B$. chitria and $B$. lyciumin in water have been used since ancient times as domestic cure for conjunctivitis, bleeding piles, ophthalmic problems, skin diseases, ulcers, jaundice, inflamed spleen and inflamed liver [40]. A decoction of some Berberis species is mixed with honey and used for treatment of jaundice and painful micturition. Extracts of Berberis plants have been effectively used for treating gynecological inflammatory diseases [11]. Attempts have been made at synthesizing some alkaloid products originally isolated from Berberis species; some of the synthetic berbamine derivatives have been found to have anti-leukemia activity [41].

Two important alkaloids (Table 2 for details), berberine and berbamine, found in Berberis plants have antioxidant, anti-hyperglycemic, antiinflammatory, heptoprotective, and hypotensive properties [42]. Aqueous extract of B. lyceum 
Table 3: Ethnomedicinal claims of Berberis species

\begin{tabular}{|c|c|c|c|c|c|c|c|c|c|c|c|c|}
\hline \multirow[t]{2}{*}{$\overline{\mathbf{S} / \mathbf{N}}$} & \multirow{2}{*}{$\begin{array}{l}\text { Botanical } \\
\text { name }\end{array}$} & \multirow[t]{2}{*}{ Local Name } & \multicolumn{9}{|c|}{ Ethnomedicinal uses* } & \multirow[b]{2}{*}{ Reference } \\
\hline & & & $\overline{\mathbf{R}}$ & Se & $\mathbf{F}$ & St & B & $\mathbf{W}$ & Fr & De & & \\
\hline 1. & B. aitchisonii & Kwary & + & - & - & + & + & - & + & - & $\begin{array}{l}\text { Has Activity against carrageenan } \\
\text { and serotonin-induced hind paw } \\
\text { oedema, acetic acid-induced } \\
\text { increased vascular permeability, } \\
\text { castor oil-induced diarrhea and } \\
\text { Freund's complete adjuvant-induced } \\
\text { arthritis models. }\end{array}$ & $\begin{array}{l}\text { Küpeli et al } \\
\text { [65] }\end{array}$ \\
\hline 2. & B. vulgaris & $\begin{array}{l}\text { Zarlog/ } \\
\text { Tor kwaray/ } \\
\text { Zarch/Zralg } \\
\text { a }\end{array}$ & + & - & - & + & + & - & + & + & $\begin{array}{l}\text { Used to heal internal injuries in man } \\
\text { and cattle. For the relief of joint } \\
\text { pain. Used the roots decoction for } \\
\text { the cure of internal injuries and for } \\
\text { the removal of kidney stones. Used } \\
\text { for sore throat and fever. Poultice of } \\
\text { pounded root or bark used for sore } \\
\text { throat. Cold and compound } \\
\text { decoctions are taken in fever. Roots } \\
\text { are boiled in water and decoction is } \\
\text { used in both human and cattle for } \\
\text { the treatment of internal injuries and } \\
\text { also used for tanning skin. }\end{array}$ & $\begin{array}{l}\text { Tantaquidgeon } \\
\text {, [66] } \\
\text { Chaudhary et } \\
\text { al [67] }\end{array}$ \\
\hline 3. & $\begin{array}{l}\text { B. } \\
\text { brandisiana }\end{array}$ & Shugloo & - & - & - & - & + & + & + & - & $\begin{array}{l}\text { Leaves decoction is useful in } \\
\text { dysentery and sore throat. Root and } \\
\text { stem bark is tonic and is frequently } \\
\text { utilized for healing of wounds and } \\
\text { arthritis. }\end{array}$ & Khan et al [5] \\
\hline 4. & $\begin{array}{l}\text { B. } \\
\text { brevissima }\end{array}$ & Zeyar largy & + & - & - & + & - & - & - & - & $\begin{array}{l}\text { Antidiabetic and antimicrobial } \\
\text { activities. }\end{array}$ & Ali et al [58] \\
\hline 5. & $\begin{array}{l}\text { B. } \\
\text { calliobotrys }\end{array}$ & Shin zaralga & - & - & - & - & + & - & + & + & $\begin{array}{l}\text { Traditionally used as a gargle for } \\
\text { pharyngitis for the relief of intestinal } \\
\text { colic. }\end{array}$ & Singh et al [30] \\
\hline 6. & B. aristata & $\begin{array}{l}\text { Kingore/Dar } \\
\text { u haldhi }\end{array}$ & + & - & - & - & + & - & + & + & $\begin{array}{l}\text { Anti-microbial, anti-pyretic, anti- } \\
\text { hepatotoxic, anti-hyperglycaemic, } \\
\text { anti-lipidemic, anti-cancer, and anti- } \\
\text { oxidant agent. Useful in the } \\
\text { treatment of gynaecological } \\
\text { disorders, diarrhoea, haemorrhoids, } \\
\text { osteoporosis, HIV-AIDS, diabetes, } \\
\text { ear and eye infections, jaundice, } \\
\text { wound healing, malarial fever and } \\
\text { skin diseases. Root extract and } \\
\text { decoction is used for eye disorders. } \\
\text { The decoction of the root of this } \\
\text { plant is used in Piles, gastric } \\
\text { disorders and other allied complaint. } \\
\text { Used in snake and scorpion bite. } \\
\text { Extract of root with butter used for } \\
\text { the treatment of bleeding piles. }\end{array}$ & $\begin{array}{l}\text { Bhattacharjee } \\
\text { et al [68] }\end{array}$ \\
\hline 7. & $\begin{array}{l}\text { B. } \\
\text { Jaeschkean } \\
a\end{array}$ & $\begin{array}{l}\text { Jaeschke's } \\
\text { /kaymali }\end{array}$ & + & + & - & - & - & - & + & - & $\begin{array}{l}\text { Used in Eye trouble, fever, stomach } \\
\text { disorders, skin diseases, blood } \\
\text { purifier, astringent, diuretic, jaundice } \\
\text { and menorrhea. Root extract is } \\
\text { commonly, used as an astringent, } \\
\text { diuretic, blood purifier and } \\
\text { alternative. It is also used in eye } \\
\text { disorders, menorrhea, jaundice and } \\
\text { skin diseases by the local tribes. }\end{array}$ & $\begin{array}{l}\text { Singh et al [30] } \\
\text { Gaur et al [69] }\end{array}$ \\
\hline 8. & B. Iycium & $\begin{array}{l}\text { Speen } \\
\text { Kwaray }\end{array}$ & + & + & + & + & - & + & - & + & $\begin{array}{l}\text { Antibacterial, anticarcinogenic, } \\
\text { carminative febrifuge and } \\
\text { ophthalmic. Fruit is used medicinally } \\
\text { for stomachache. Fruits are used as } \\
\text { coagulant. }\end{array}$ & Jee et al [70] \\
\hline
\end{tabular}


Table 3: Ethnomedicinal claims of Berberis species (continued)

\begin{tabular}{|c|c|c|c|c|c|c|c|c|c|c|c|c|}
\hline \multirow[t]{2}{*}{$\mathbf{S} / \mathbf{N}$} & \multirow{2}{*}{$\begin{array}{l}\text { Botanical } \\
\text { name }\end{array}$} & \multirow[t]{2}{*}{ Local Name } & \multicolumn{9}{|c|}{ Ethnomedicinal uses ${ }^{*}$} & \multirow[b]{2}{*}{ Reference } \\
\hline & & & $\overline{\mathbf{R}}$ & Se & $\mathbf{F}$ & St & B & $\mathbf{W}$ & Fr & De & & \\
\hline 9. & $\begin{array}{l}\text { B. } \\
\text { orthobotrys }\end{array}$ & Kishmal & + & - & - & + & + & - & - & - & $\begin{array}{l}\text { Used for external and internal } \\
\text { wounds, infections, jaundice, piles, } \\
\text { liver problems, kidney stone, } \\
\text { swellings, sore throat, diabetes, } \\
\text { bleeding, leucorrhoea, uterine } \\
\text { tumors and its related problems. } \\
\text { The extract of stem and root bark } \\
\text { has been used in stomach ulcers } \\
\text { and other related problems. }\end{array}$ & $\begin{array}{l}\text { Khan and } \\
\text { Khatoon [64] } \\
\text { Akhtar et al } \\
\text { [71] }\end{array}$ \\
\hline 10. & $\begin{array}{l}\text { B. } \\
\text { pachyacant } \\
\text { ha }\end{array}$ & Karpa & + & - & - & - & - & - & + & - & $\begin{array}{l}\text { Traditionally used to treat stomach } \\
\text { trouble, fever and dye }\end{array}$ & Singh et al [30] \\
\hline 11. & $\begin{array}{l}\text { B. } \\
\text { parkeriana }\end{array}$ & $\begin{array}{l}\text { Kala } \\
\text { Simbloo }\end{array}$ & & & & & & & & & $\begin{array}{l}\text { Antidiabetic and antimicrobial } \\
\text { activities. }\end{array}$ & Ali et al [58] \\
\hline 12. & $\begin{array}{l}\text { B. } \\
\text { pseudumbel } \\
\text { lata }\end{array}$ & $\begin{array}{l}\text { Kashmal/kw } \\
\text { arai }\end{array}$ & + & - & - & - & + & + & + & - & $\begin{array}{l}\text { Traditionally used as astringent, } \\
\text { diuretic and as cure for jaundice, } \\
\text { Intestinal disorders, eye trouble, } \\
\text { oxytocic and throat ache. }\end{array}$ & Singh et al [30] \\
\hline \multirow[t]{5}{*}{13.} & B. ulicina & $\begin{array}{l}\text { Gorse } \\
\text { Barberry }\end{array}$ & + & - & - & - & + & - & - & - & $\begin{array}{l}\text { Against ringworm. cholagogue, } \\
\text { antidiarrhoeal, stomachic, laxative, } \\
\text { Diaphoretic, antipyretic, antiseptic. }\end{array}$ & Khare [72] \\
\hline & & & & & & & & & & & $\begin{array}{l}\text { Used externally in opthalmia, } \\
\text { conjunctivitis, ulcers, sores, swollen } \\
\text { gums. }\end{array}$ & \\
\hline & & & & & & & & & & & $\begin{array}{l}\text { Have Anti-inflammatory, } \\
\text { hypoglycaemic, hypotensive, } \\
\text { antiamoebic, anticoagulant, } \\
\text { antibacterial activities. }\end{array}$ & \\
\hline & & & & & & & & & & & $\begin{array}{l}\text { Bark used in liver complaints, } \\
\text { diarrhoea, dysentery, cholera, } \\
\text { gastric disorders enlargement of } \\
\text { spleen and for regulating } \\
\text { metabolism. }\end{array}$ & \\
\hline & & & & & & & & & & & $\begin{array}{l}\text { Berries are used as antiscorbutic } \\
\text { and laxative. }\end{array}$ & \\
\hline
\end{tabular}

showed hypotensive effects in dogs, and reduced mean arterial pressure in cats [43].

B. aristata, an extensively studied species of Berberis genus, is reported to have a number of pharmacological and clinical uses. Extracts of its root appear to be better treatment option for malaria (compared to cinchona and quinine), because it does not cause cardiac depression during treatment of intermittent fever in malaria $[65,68]$. Butter is mixed with powdered root and used for the treatment of bleeding piles. Cambium paste of $B$. aristata is used for the treatment of rheumatism [44]. The best clinical use includes treatment of diarrhea due to viral, protozoal, bacterial and fungal infections [45]. Ripe $B$. aristata exhibits hypochlolestrolemic activity and is used as a mild laxative for children [34].

\section{ANTIMICROBIAL ACTIVITIES OF GENUS BERBERIS SPECIES}

$B$. aristata, B. chitria and B. Iycium are three important species of Berberis found in Pakistan. Extracts of these species have very good antimicrobial activities. Details of medicinal uses of Berberis species are indicated in Table 3 . Berberine, an alkaloid from Berberis, has activity against Gram positive and Gram negative bacteria as well as antifungal activities $[26,47,48]$. These differences in susceptibilities might be due to the differences in the cell wall composition of Gram negative and Gram positive bacteria. Moreover, extracts obtained from $B$. lycium have strong antibacterial activity as compared to those of $B$. aristata and $B$. chitria. [48]. Sharma and colleagues reported that ethanolic root extract of $B$. aristata shows 
antifungal activity [47]. More detailed studies showed that extracts from B. aristata (aqueous andalcoholic extracts; and colloidal suspension of powdered root in distilled water) have antifungal activities against Candida and Aspergillus species [26]. These extracts also exhibit antibacterial activity against gramnegative bacteria (Salmonella typhimurium, Escherichia coli, Shigella dysenteriae type 1 and Vibrio cholerae. B. aristata root extracts have low minimum inhibitory concentration (MICs) values against Bacillus cereus, Escherichia coli, Staphylococcus aureus and Aspergillus flavus, while the stem extract has been reported effective against Bacillus cereus and Streptococcus pneumonia $[26,47,48]$. In vitro, ethanolic extracts of $B$. aristata showed inhibitory effects against Propionibacterium acnes [50].

Berberine; an alkaloid isolated from Berberis species has been used as anti-diarrheal medication from time immemorial. It has been reported to inhibit the secretory responses of heat-labile enterotoxins of $E$. coli and $V$. cholera in rabbit ligated intestinal loop model [49]. Orally administered berberine resulted in more effective elimination of parasites than other established drugs [51].

Hydro-alcohol (50\%) extract of air-dried roots and stems of $B$. lycium has exhibit antibacterial activity against Micrococcus luteum, B. cereus, Enterobacter aerogenes, Klebsiella pneumonia, E. coli, Proteus mirabilis, Staphylococcus aureus, Pseudomonas aeruginosa and Streptococcus pneumonia [52]. The root extract also showed antifungal activities against fungal strains of Aspergillus terreus, Aspergillus flavus and Aspergillus spinulosus, while the stem extract inhibited only Aspergillus spinulosus. The hydroalcoholic extract exhibited stronger and broader range against bacterial strains than fungal strains [52]. These findings show that main berberine might be has promising antimicrobial potential. When $B$. lycium was mixed in drinking water of broilers along with other medicinal plants showed good immune boosting activity against Newcastle disease, infectious bursal disease and infectious bronchitis. A significant reduction in coccidial oocysts per gram of feces was also noticed [53].

\section{ANTI-DIABETIC ACTIVITY}

Studies have shown that $B$. aristata roots have potent and orally effective anti-diabetic constituents which either promote insulin secretion or have insulin-like effects [54]. Ethanolic and methanolic extracts of stem bark of
B. aristata have significant anti-hyperglycemic effect in alloxan-induced diabetic rats. The antioxidant and anti-hyperglycemic activity of 50 $\%$ aqueous ethanolic extracts of $B$. aristata roots have been reported in alloxan induced diabetic rats. Aqueous ethanolic extracts, besides being safe also lowered blood glucose significantly with no hypoglycemic effect on the control groups. Root extracts of $B$. aristata are also reported to have strong tendencies to regulate glucose homeostasis through decreased gluconeogenesis [45].

Crude powder Berberis species has been reported to decrease level of glucose in blood both in diabetic and normal rabbits $[17,55]$. The root bark extracts of $B$. Iycium in various solvents including water, aqueous methanolic, methanolic, chloroform and n-hexane were prepared and screened for their antidiabetic activities in alloxanized rabbits. Results revealed that amongst the extracts, water extract (500 mg/kg) showed maximum hypoglycemic activity when administered orally, for almost $6 \mathrm{~h}$. Similar doses of aqueous methanol, methanol, and n-hexane extract reduced blood glucose levels for $4 \mathrm{~h}$. The chloroform extract did not show any significant anti-diabetic activity [17,55]. Ethanolic and aqueous extracts of the roots of the plant were administered in normal and alloxanized rats and $20 \mathrm{mg} / \mathrm{kg}$ glibenclamide was utilized as a control drug. Water extract was further compared in combination with insulin. The 50 and $100 \mathrm{mg} / \mathrm{kg}$ doses reduced hyperglycemia after 3 to $5 \mathrm{~h}$ of administration. Oral glucose tolerance tests showed that the plant extracts decreased serum glucose in a dose-dependent manner [55]. The mechanism involved in the hypoglycemic effects may involve insulin-like effects, possibly through increased peripheral glucose consumption [56]. Anti-diabetic activity of pure berberine was compared with that of ethanolic root extract of $B$. lycium in normal and alloxan-induced diabetic rats using similar doses $(50 \mathrm{mg} / \mathrm{kg})$ of each. Both treatments reduced blood glucose levels significantly and demonstrated significant effects on glycosylated haemoglobin, glucose tolerance, serum lipid profiles and animal body weights. Thus the root extract was comparable in efficacy with berberine [56]. Moreover, aqueous root extract of $B$. vulgaris shows potent and significant hypoglycemic effects in streptozotocin-induced diabetic rats, with significant increases in serum cholesterol and serum triglycerides levels [57]. B. brevissima and $B$. parkeriana are also have anti-diabetic activities [58]. 


\section{ANTI-INFLAMMATORY ACTIVITIES}

Topical application of aqueous extracts $B$. aristata showed potent anti-inflammatory activity against endotoxin-induced uveitis in rabbits. Anterior uveitis was induced in rabbits by intravitreal injection of lipopolysaccharide from $E$. coli after pre-treatment with $B$. aristata aqueous extracts [59]. Alcoholic extract of $B$. aristata was found to have moderate anti-proteolytic activity toward trypsin-induced hydrolysis of bovine serum albumin, but no inhibitory activity against $\beta$.-glucuronidase [60]. Aqueous extracts of the plant were effective in arresting the initial phases of acute inflammation, while the alcoholic extracts worked better at the later phases of acute inflammation. Studies indicate that the alcoholic extract acts by hindering the release of mediators of late-phase mediators e.g. prostaglandin, while the aqueous extracts blocks the mediators released in the early phase (i.e. bradykinin, serotonin and histamine), as well as mediators released in the later phase e.g. prostaglandin [26].

B. baluchistanicais is a popular species found in Pakistan (Balochistan). This plant is reported in folklore pharmacopeias for its different medicinal uses. Decoction of roots is used against cough and internal injury of livestock and human beings. Two new alkaloids (pakistanamine and pakistanine) and a new phenolic bisbenzylisoquinoline alkaloid, (+)-baluchistine, have been isolated from $B$. baluchistanica [35].

\section{ANTIOXIDANT ACTIVITIES}

Aqueous and ethanolic extracts of roots of $B$. aristata roots have been studied for their antioxidant potential, and results obtained showed that they decreased oxidative stress [45]. In addition, aqueous and methanolic extracts of the aerial parts of $B$. aristata, significantly improved antioxidant status in $\mathrm{CCl}_{4}-$ induced liver injury [61]. The antioxidant properties of the fruits of $B$. Iycium have also been studied, with respect to DPPH radical scavenging potential of its phytochemicals [62]. These compounds include, 4, 4 dimethyl hexadeca 3-ol, berberine, $\beta$-sitosterol, 3-[4-(6methyl butyl) phenyl] propan-1-ol and butyl -3hydroxypropyl phthalate.

\section{ANTICANCER ACTIVITIES}

Methanolic extract of the stem of $B$. aristata was screened for anticancer potential against human colon cancer cell line and found to be effective.
The extract also showed concentrationdependent inhibition of HT29 cells. Indeed, berberine, an alkaloid isolated from the plant $B$. aristata, has been reported to significantly inhibit carcinogenesis induced by 20-methylcholanthrene or nitrosodiethylamine, in a dosedependent manner in small animals [63].

\section{WOUND HEALING PROPERTIES}

Root extracts of $B$. Iycium have been studied in Swiss Wistar rats for their wound-healing potential. Methanolic and aqueous extracts of the plant roots were examined using incision, excision and dead wound space models of wound repair. Both extracts increased the area of epithelization and also showed increase in breaking potency. In aqueous extract-treated group, moderate collagen deposition, fibroblasts and macrophages were found, whereas a significant increase in collagen deposition with lesser macrophages and fibroblasts were observed in methanol extract-treated group. A significant increase in dry weight and hydroxyproline content of granulation tissue was also observed. It was shown that methanolic extract was more effective than the aqueous extract [64].

\section{Pakistani perspective}

The altitudes in Pakistan range from 0 to $8611 \mathrm{~m}$, with a unique geography rich in floral diversity. Therefore the public interest is focused on indigenous plants and these medicinal plants have great value for scientists like ethnobotanists, anthropologists, pharmaceutical chemists, and physicians [2]. Pakistan has more than 6,000 species of valuable medicinal plants [73]. It is one of the leading countries which export medicinal plants to international markets [74]. The medicinal plants are mostly collected by untrained hands, and their identification and storage depends on inherited knowledge from elders. Some plant species are considered for a specific disease and illness, while some have mixed usage. In many cases, closely related species to the desired one, are collected and sold under one name, leading to nonachievement of the desired results. Recent reports indicate only 14 species of Berberis in Pakistan which contradicts the earlier figure of 19 species. A trained plant taxonomist and good herbaria are necessary for identification and collection of desired plant species but their numbers are decreasing worldwide especially in Pakistan [5,64]. 


\section{CONCLUSION}

The actual number of Berberis species could be more than those discovered so far. Therefore, conservation strategies are needed for these medicinal plants. Trained plant taxonomists and good herbaria are necessary for identification and collection of desired plant species. Berberis species are rich sources of phytonutrients and have important pharmacological properties such as anti-cancer, antibacterial, anti-viral, antidaibetic, antioxidant, cholesterol-lowering and anti-hypertensive potential (table 3). A good number of phytochemical and pharmacological studies in Pakistan have been carried out on $B$. aristata, followed by $B$. vulgaris and $B$. lycium. Studies reported from Western countries mainly emphasized the chemistry of the different Berberis plants and isolation of new lead compounds. In view of their bioactive compounds the development and discovery of new activities in related species are very important.

Phytochemical and pharmacological studies (Table 1 and 2) of the genus Berberis have received more interest in the recent past. These include investigation of its potential towards cardiovascular, hepato-protective, anti-microbial and anti-cancer activities. Berberis species from Pakistan are not well investigated for anti-cancer and anti-diabetic potential. Further research should be focused on human cell culture systems to elucidate the anti-cancer potential and antidiabetes activities of the species from this genus.

\section{DECLARATIONS}

\section{Conflict of Interest}

No conflict of interest associated with this work.

\section{Contribution of Authors}

The authors declare that this work was done by the authors named in this article and all liabilities pertaining to claims relating to the content of this article will be borne by them. ZKS conceived the study. IK and SN drafted the manuscript. MA and IK revised the manuscript. All the authors read approved the manuscript.

\section{REFERENCES}

1. Nwachukwu C, Umeh C, Kalu I et al. Identification and traditional uses of some common medicinal plants in Ezinihitte Mbaise LGA, of Imo State, Nigeria. Report Opin 2010; 2: p1.
2. Sher H, Midrarullah A, Khan FH, S. A. Medicinal plants of Udigram, District Swat, Pakistan. Pak. J. Forest 2003; 53: 65-74.

3. Khalil AT, Khan I, Ahmad K, et al. Synergistic antibacterial effect of honey and Herba Ocimi Basilici against some bacterial pathogens. Journal of Traditional Chinese Medicine 2013; 33: 810-814.

4. Khalil AT, Shinwari ZK, Qaiser M, Marwat KB. Phytotherapeutic claims about euphorbeaceous plants belonging to Pakistan; an ethnomedicinal review. Pak. J. Bot 2014; 46: 1137-1144.

5. Khan T, Khan IA, Rehman A. A review on Berberis species reported from Gilgit-Baltistan and Central Karakoram National Park, Pakistan. Journal of Medicinal Plants 2014; 2: 16-20.

6. Rao $R$, Husain $T$, Dutt $B$, Garg A. Revision of the family Berberidaceae of India: 1. Rheedea 1998; 8: 1-66.

7. Shinwari Z, Watanabe T, Rehman M, Youshikawa T. A pictorial guide to Medicinal Plants of Pakistan. KUST. Kohat, Pakistan 2006.

8. Shinwari ZK, Khan AA, Nakaike $T$, Kyōkai NSH. Medicinal and other useful plants of District Swat, Pakistan. ZK Shinwari 2003.

9. Shinwari Z, Gilani S, Kohjoma M, Nakaike T. Status of medicinal plants in Pakistani Hindukush Himalayas. Proceedings of Nepal-Japan Joint Symposium on Conservation and utilization of Himalayan Med. Resour 2000; 257-264.

10. Srivastava $S$, Srivastava $M$, Misra $A$ et al. $A$ review on biological and chemical diversity in Berberis (Berberidaceae). 2015.

11. Bhardwaj D, Kaushik N. Phytochemical and pharmacological studies in genus Berberis. Phytochemistry reviews 2012; 11: 523-542.

12. Haji A. Functional dyeing of wool with natural dye extracted from Berberis vulgaris wood and Rumex hymenosepolus root as biomordant. Iran. J. Chem. Chem. Eng. Vol 2010; 29.

13. Ikram M. review on the chemical and pharmacological aspects of genus Berberis. Plant Med 1975.

14. Karimov A. Berberis alkaloids. Chemistry of natural compounds 1993; 29: 415-438.

15. Valencia $E$, Weiss $I$, Firdous $S$ et al. The isoindolobenzazepine alkaloids. Tetrahedron 1984; 40: 3957-3962.

16. Rajasekaran A, Pokhriyal $R$, Singh $Y$. Quantitative estimation of berberine in roots of different provenances of Berberis aristata DC by HPLC and study of their antifungal properties. Pharmacognosy Magazine 2009; 5: 355.

17. Ahmed B, Masoodi MH, Khan S. Pachycanthine: A new isoquinoline alkaloid and its antihepatotoxic activity from Berberis pachycantha Koehne. Indian journal of chemistry. Section B, Organic including medicinal 2008; 47: 945.

18. Torres R, Dellemonache F, Marinibettolo G. Biogenetic relationships between lignans and alkaloids in Berberis 
genus-lignans and berbamine from Berberis chilensis. Planta Medica (Germany, FR) 1979.

19. Khamidov I, Aripova S, Telezhenetskaya $M$ et al. Berberis alkaloids XXXVI. Turcomanidine-A new alkaloid from Berberis turcomanica. Chemistry of natural compounds 1996; 32: 873-875.

20. Khamidov I, Tashkhodzhaev B, Aripova $S$ et al. Berberis alkaloids. XXXVII. Investigation of the alkaloids ofB. oblongata andB. integerrima. Crystal structure of 8trichloromethyldihydroberberine. Chemistry of natural compounds 1996; 32: 876-879.

21. Gorval' L, Grishkovets V. Alkaloids of some species of the genusBerberis introduced into the Crimea. Chemistry of natural compounds 1999; 35: 223-224.

22. Sivakumar $R$, Kamachandran Nair $A$. Polyphenolic constituents of the flowers of Berberis aristata. Journal of the Indian Chemical Society 1991; 68: 531-532.

23. Andola HC, Rawal RS, Bhatt ID. Comparative studies on the nutritive and anti-nutritive properties of fruits in selected Berberis species of West Himalaya, India. Food Research International 2011; 44: 2352-2356.

24. Andola HC, Rawal R, Rawat $M$ et al. Variations of berberine contents in Berberis pseudumbellata: $A$ high value medicinal shrub of west Himalaya, India. Medicinal Plants-International Journal of Phytomedicines and Related Industries 2010; 2: 111115.

25. Kim S, Han J, Lee SK et al. Berberine suppresses the TPA-induced MMP-1 and MMP-9 expressions through the inhibition of PKC- $\alpha$ in breast cancer cells. Journal of Surgical Research 2012; 176: e21-e29.

26. Shahid M, Rahim T, Shahzad $A$ et al. Ethnobotanical studies on Berberis aristata DC. root extracts. African Journal of Biotechnology 2009; 8.

27. Hesse M. Alkaloids: nature's curse or blessing? WileyVCH 2002.

28. Miana G. Tertiary dihydroprotoberberine alkaloids of Berberis lycium. Phytochemistry 1973.

29. Upwar NK, Patel R, Waseem N, Mahobia NK. Hypoglycemic effect of methanolic extract of Berberis aristata DC stem on normal and streptozotocin induced diabetic rats. Int J Pharm Pharm Sci 2011; 3: 222-224.

30. Singh $A$, Lal M, Samant S. Diversity, indigenous uses and conservation prioritization of medicinal plants in Lahaul valley, proposed Cold Desert Biosphere Reserve, India. International Journal of Biodiversity Science \& Management 2009; 5: 132-154.

31. Tiwari UL, Singh Adhikari B. Berberis rawatii $s p$. nov.(Berberidaceae) from India. Nordic Journal of Botany 2011; 29: 184-188.

32. Hussain SF, Shamma M. Kalashine, a novel type aporphine-benzylisoquinoline alkaloid. Tetrahedron Letters 1980; 21: 3315-3318.

33. Hussain SF, Siddiqui MT, Khan $L$ et al. Berbamine 2'- $\beta$ $N$-oxide, a New Bisbenzylisoquinoline from Berberis brandisiana. Journal of Natural Products 1986; 49: 538539.
34. Rashmi, A. R, Pant J. The genus Berberis linn.: A review. Pharmacognosy Reviews 2008; 2: 369-385.

35. Kakar SA, Tareen RB, Kakar MA et al. Screening of antibacterial activity of four medicinal plants of Balochistan-Pakistan. Pak. J. Bot 2012; 44: 245-250.

36. Ahmed $H$. Studies on the constituents of Berberis waziristanica and cd studies of chiral metal complexes. In. University of Karachi, Karachi 1992.

37. Alamzeb M, Khan MR, Mamoon-Ur-Rashid et al. Isolation, structure elucidation and enzyme inhibition studies of a new hydroxy ester and other compounds from Berberis jaeschkeana Schneid stem. Natural product research 2015; 1-6.

38. Hussaini FA, Shoeb A. Isoquinoline derived alkaloids from Berberis chitria. Phytochemistry 1985; 24: 633.

39. Dev S. selection of prime ayurvedic plant drugs. Anamaya publishers 2006.

40. Rajasekaran A, Kumar N. Rasont-a traditional crude drug prepared from Berberis sp. and its uses. Indian $J$ Tradit Know 2009; 8: 562-563.

41. Xie J, Ma T, Gu Y et al. Berbamine derivatives: a novel class of compounds for anti-leukemia activity. European journal of medicinal chemistry 2009; 44: 3293-3298.

42. Končić $M Z$, Kremer D, Karlović K, Kosalec I. Evaluation of antioxidant activities and phenolic content of Berberis vulgaris $L$. and Berberis croatica Horvat. Food and chemical toxicology 2010; 48: 2176-2180.

43. Khan I, Qayum A, Qureshi Z. Study of the hypotensive action of berbamine, an alkaloid isolated from Berberis lycium. Life sciences 1969; 8: 993-1001.

44. Uprety $Y$, Asselin H, Boon EK et al. Indigenous use and bio-efficacy of medicinal plants in the Rasuwa District, Central Nepal. Journal of Ethnobiology and Ethnomedicine 2010; 6.

45. Singh J, Kakkar P. Antihyperglycemic and antioxidant effect of Berberis aristata root extract and its role in regulating carbohydrate metabolism in diabetic rats. Journal of ethnopharmacology 2009; 123: 22-26.

46. Rashmi PJ, Rajasekaran A, Rekha P, YP. S. Quantitative estimation of berberine in roots of different provenances of Berberis aristata DC by HPLC and study of their antifungal properties. Pharmacog Mag. 2009; 5: 355358.

47. Sharma RS, Mishra V, Singh $R$ et al. Antifungal activity of some Himalayan medicinal plants and cultivated ornamental species. Fitoterapia 2008; 79: 589-591.

48. Grosvenor PW, Supriono A, Gray DO. Medicinal plants from Riau Province, Sumatra, Indonesia. Part 2: antibacterial and antifungal activity. Journal of ethnopharmacology 1995; 45: 97-111.

49. Komal S, Ranjan B, Neelam $C$ et al. Berberis aristata: $A$ review. Int J Res Ayvd Pharm 2011; 2: 383-388.

50. Kumar G, Jayaveera K, Kumar C et al. Antimicrobial effects of Indian medicinal plants against acne-inducing bacteria. Tropical Journal of Pharmaceutical Research 2007; 6: 717-723. 
51. Gupte S. Use of berberine in treatment of giardiasis. American Journal of Diseases of Children 1975; 129: 866-866.

52. Singh M, Srivastava S, Rawat A. Antimicrobial studies of stem of different Berberis species. Nat Prod Sci 2009; 15: 60-65.

53. Nidaullah H, Durrani F, Ahmad $S$ et al. Aqueous extract from different medicinal plants as anticoccidial, growth promotive and immunostimulant in broilers. Journal of agricultural and biological science 2010.

54. Akhtar MS, Sajid SM, Akhtar MS, Ahmad M. Hypoglycaemic effect of Berberis aristata roots, aqueous and methanolic extracts in normal and alloxandiabetic rabbits. Pharmacologyonline 2008; 2: 845-856.

55. Ahmed M, Alamgeer A, Sharif $T$ et al. Effect of berberis lycium royle on lipid profile in alloxan induced diabetic rabbits. Ethnobotanical leaflets 2009; 2009: 4.

56. Gulfraz M, Qadir G, Nosheen F, Parveen $Z$. Antihyperglycemic effects of Berberis lyceum Royle in alloxan induced diabetic rats. Diabetologia croatica 2007; 36: 49-54.

57. Meliani N, Dib MEA, Allali H, Tabti B. Hypoglycaemic effect of Berberis vulgaris $L$. in normal and streptozotocin-induced diabetic rats. Asian Pacific journal of tropical biomedicine 2011; 1: 468-471.

58. Ali S, Igoli J, Clements $C$ et al. Antidiabetic and antimicrobial activities of fractions and compounds isolated from Berberis brevissima Jafri and Berberis parkeriana Schneid. Bangladesh Journal of Pharmacology 2013; 8: 336-342.

59. Gupta SK, Agarwal $R$, Srivastava $S$ et al. The antiinflammatory effects of Curcuma longa and Berberis aristata in endotoxin-induced uveitis in rabbits. Investigative ophthalmology \& visual science 2008; 49 : 4036-4040.

60. Gacche R, Dhole N. Antioxidant and possible antiinflammatory potential of selected medicinal plants prescribed in the Indian traditional system of medicine. Pharmaceutical biology 2006; 44: 389-395.

61. Tiwari BK, Khosa R. Evaluation of the hepatoprotective and antioxidant effect of Berberis asiatica against experimentally induced liver injury in rats. International Journal of Pharmacy and Pharmaceutical Sciences 2010; 2: 92-97.
62. Sabir S, Tahir K, Rashid N et al. Phytochemical and antioxidant studies of Berberis lycium. Pakistan journal of pharmaceutical sciences 2013; 26: 1165-1172.

63. Mazumder PM, Das S, Das S, Das MK. Cytotoxic Activity of Methanolic Extracts of Berberis aristata $D C$ and Hemidesmus indicus R. Br. in MCF7 Cell Line. Journal of Current Pharmaceutical Research 2010; 1: 12-15.

64. Khan SW, Khatoon S. Ethno botanical studies on useful trees and shrubs of Haramosh and Bugrote valleys In Gilgit Notheren areas of Pakistan. Pak J Bot 2007; 39: 699-710.

65. Küpeli E, Koşar M, Yeşilada E, Başer KHC. A comparative study on the anti-inflammatory, antinociceptive and antipyretic effects of isoquinoline alkaloids from the roots of Turkish Berberis species. Life sciences 2002; 72: 645-657.

66. Tantaquidgeon G. Mohegan Medicinal Practices, Weather-Lore and Superstitions. SI-BAE Annual Report 1928; 43: 264-270.

67. Chaudhary R, Guha HN, Chaudhary AR, DC. P. Ethnobotanical uses of Herbaria II. J Eco Taxo Bot. 1980; 1: 163-168.

68. Bhattacharjee S, Tiwari K, Majumdar R, Misra A. Folklore medicine from district Kamrup (Assam). Bull MedicEthno-Bot Res 1980; 1.

69. Gaur R, Semwal J, Tiwari J. A survey of high altitude medicinal plants of Garhwal Himalaya. Bull. Medicoethnobot. Res., 1983, 4, 102 1983; 106.

70. Jee V, Dar G, Kachroo P, Bhat G. Taxo-ethnobotanical studies of the rural areas in district Rajouri (Jammu). J. Econ. Taxon. Bot 1984; 5: 831-838.

71. Akhtar M, Jabeen Q, Bashir S et al. Possible mechanism of cardiac depressant activity of Berberis orthobotrys $r$ oots in isolated rabbit heart. Acta poloniae pharmaceutica 2013; 71: 667-675.

72. Khare CP. Indian medicinal plants: an illustrated dictionary. Springer Science \& Business Media 2008.

73. Ali H, Qaiser M. The ethnobotany of Chitral valley, Pakistan with particular reference to medicinal plants. Pak. J. Bot 2009; 41: 2009-2041.

74. Hussain J, Khan AL, Rehman $N$ et al. Proximate and nutrient analysis of selected vegetable species: $A$ case study of Karak region, Pakistan. African Journal of Biotechnology 2009; 8. 